\title{
Consumers Knowledge About Health Effects of Edible Oils and Fats in Turkey: A Questionnaire Study
}

\author{
Zeynep Aksoylu Özbek, Kıvılcım Çelik and Pelin Güinç Ergönüil*
}

Manisa Celal Bayar University, Engineering Faculty, Department of Food Engineering, Manisa/ Turkey

\section{ISSN: 2640-9208}

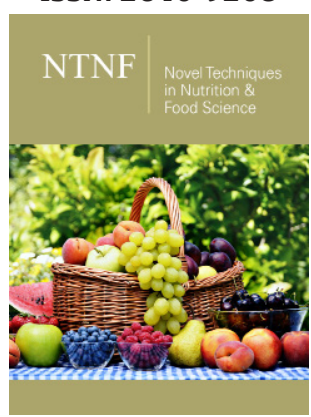

${ }^{* 1}$ Corresponding author: Pelin Günç Ergönül, Department of Food Engineering, Turkey

Submission: 温January 24, 2020

Published: 留February 03, 2020

Volume 4 - Issue 4

How to cite this article: Zeynep Aksoylu Özbek, Kıvılcım Çelik, Pelin Günç Ergönül. Consumers Knowledge About Health Effects of Edible Oils and Fats in Turkey: A Questionnaire Study. Nov Tech Nutri Food Sci. 4(5).NTNF.000596.2020.

DOI: 10.31031/NTNF.2020.04.000596

Copyright@ Pelin Günç Ergönül. This article is distributed under the terms of the Creative Commons Attribution 4.0 International License, which permits unrestricted use and redistribution provided that the original author and source are credited.

\section{Abstract}

The aim of this study is to identify the predictors of edible oil and fat consumption. A questionnaire to evaluate the attitude of consumers toward various edible oils and fats was administered to 300 individuals in Manisa. Twenty six percent of participants reported olive oil is the healthiest edible oil. Most of the participants believed that consumption of oils does not lead to health risk if it is not consumed too much. Margarine was reported as the most cholesterol containing item. Fats were associated with health concerns by majority of participants. Seventy six percent of participants believed that there was a relationship between oil and fat consumption and cardiovascular diseases. The findings of this study suggest that Turkish consumers hold positive attitudes towards edible oils such as olive oil and other vegetable oils. On the other hand, they are aware of the health risks linked to fat consumption.

Keywords: Consumption; Fat; Health; Oil; Questionnaire; Turkey

\section{Introduction}

Nutritional habits of human beings have undergone radical changes over time. A number of studies have shown that there is a relationship between eating habits of people and the diseases that they encounter. Therefore, especially in developed countries, people who want to live a healthy life take care of their nutrition. In a balanced diet, carbohydrates, proteins and fats play an important role. People can obtain their fat needs from vegetable and animal origin foods.

Fats and oils are carriers of various nutrients and fat-soluble vitamins found in foods as well as being one of the most important energy sources [1]. Fats, which are one of three basic nutrients, meet the majority of human organism energy needs and have many other physiological and biological functions [2]. Lipids have numerous biological functions in the body and act as the structural material of all cells and organs [1]. Fats are essential because they contain essential fatty acids and vitamins A,D,E,K and also have flavor-enhancing properties. They are significant elements in terms of their contribution to human health and high nutritional value [3,4]. Additionally, they improve textural quality of foods [5,6]. Besides serving as thermal insulator for human body and protector of internal organs against external influences, fats also have important roles in hormone synthesis, intelligence and reproductive organs $[3,5,7]$. There are two aspects of lipid requirement in human nutrition: qualitative and quantitative. Firstly; some lipids contain essential fatty acids and fat-soluble vitamins, so there is a need for health [8]. Then, $25-30 \%$ of total daily calorie necessity in a normal diet should be provided by oils [8,9]. In developed countries, $35-40 \%$ for children, $30-35 \%$ for young people and for adults $25-30 \%$ of daily consumed calorie is provided by fats. In developing countries, this rate is as low as 5\% [8]. An adult person should consume about $24 \mathrm{~kg}$ of fat per year [4]. In 2016, a total of 966.000 tons of vegetable oils (including olive oil) were produced in Turkey. The amount of vegetable oil per capita was determined as $21.9 \mathrm{~kg}[10,11]$.

Experts have introduced nutritional guidelines to deal with malnutrition. However, many countries make effort to prevent chronic illnesses such as heart disease, obesity and diabetes, and re-prepare these dietary guidelines. Nutritional recommendations continue to emphasize the low-fat and total fat-free diet to reduce the risk of obesity and the risk of diabetes and cardiovascular disease [12]. The American Heart Association recommends that dietary intake of saturated fat should be between 5-6\% per day [13]. On the other hand, a 
daily intake of cholesterol less than $300 \mathrm{mg}$ is suggested by FDA [14]. Excessive consumption of saturated fats and cholesterol is known to increase the amount of LDL, a low-density lipoprotein, namely bad cholesterol. This leads to increase of coronary heart disease risk [5,6,13-15].

Most of the vegetable oils are obtained from seeds such as sunflower, canola, soybean and cotton. They are also derived from olives and palm fruits, and $97-99 \%$ of its composition consists of triglycerides [16]. Cooking oils and fats may be of vegetable or animal origin. Olives in the Mediterranean, rapeseed in Europe, sesame seeds in India and soybean in China have been used as oil rich products for centuries. Today; $80 \%$ of the world's oil and fat production consists of vegetable oils and soybean oil is the most commonly used as diet oil [5]. In Turkey, the most consumed oils are sunflower and olive oils $[4,17]$. Sunflower oil contains very high proportion of polyunsaturated fatty acids. Among these, approximately $68-72 \%$ of the total fatty acid content is composed of linoleic acid, which reduces cardiovascular risk and also shows hypocholesterolemia effect. It also contains vitamins A,D,E,K and natural antioxidants such as $\alpha$-tocopherol [18-21]. Olive oil is composed of $98 \%$ triacylglycerol, the majority of them is triolein (000) which is beneficial for health [22].

When the benefits of olive oil are examined; it is known to be effective in the prevention of cardiovascular, hypertension, cancer, digestive system and nervous system diseases and has cell retention and aging retarding effects $[22,23]$. Up to now a lot of survey studies have been conducted about edible vegetable oils, olive oil, animal fat consumption habits and buying attitudes of individuals [4,24-38]. However, to the best of our knowledge, no study has been carried out to examine consumers awareness about the effects of edible vegetable and animal fats on human health. In Manisa, which was selected as a research area, no survey study has been found on this subject. Therefore, the aim of this study is to determine the health criteria of edible oil consumption of consumers by evaluating different income groups living in Manisa and to determine consumer attitude towards edible oils in terms of health.

\section{Materials and Methods}

The sample of the study included volunteer and randomly selected 300 subjects living in the central district of Manisa who fully completed questionnaire in 2014. Manisa is one of the major cities of Aegean Region and Turkey with its booming economy and growing population. Along with the increasing population, the need for oil consumption, is constantly increasing. Manisa has two central districts, namely Şehzadeler and Yunusemre. Their populations were 166.443, and 204.436, respectively in 2014 [39]. The size of the sample was estimated using population proportion through simple random sampling as follows:

$$
n=(N \times P(1-P)) /\left((N-1) \sigma_{-} p^{\wedge} 2+P(1-P)\right)
$$

Here,

$\mathrm{N}=$ the actual size of the target population (total of 370.879)

$\mathrm{P}=$ estimated proportion of the population (0.5)

$\sigma p=$ desired variance of the population (confidence interval of $95 \%$ and error margin of $0.075,1.96$ $\sigma \mathrm{p}=0.075, \sigma \mathrm{p}=0.038265$ ) [40].

A sample of 171 observations is needed. However, questionnaire was administered to 300 participants to ensure the reliability of the study. A 17-items questionnaire was developed after administration of pre-test to 15 individuals to assure its understandability. It was divided into two parts. In the first part, 6 questions about sociodemographic characteristics were asked to subject, while 11 questions in the second part were asked to evaluate their awareness about the health effects of edible oils and fats. The survey was conducted using face-to-face interview technique. The questionnaire took approximately 15 minutes to complete. Data were evaluated using simple statistical methods in Excel.

\section{Result and Discussion}

\section{Sociodemographic characteristics of the participants}

The sociodemographic characteristics of individuals participating in the survey are summarized in Table 1. 300 individuals consisting of 150 females and 150 males participated in this study. The participants had an almost equal age distribution. A little more than half of the participants hold a bachelor's degree diploma (51\%). Most of the participants were married (57\%), and almost one-third of participants reported a monthly household income more than 3000 Turkish Lira (28\%).

Table 1: Sociodemographic characteristics of participants.

\begin{tabular}{|c|c|c|}
\hline Characteristic & n & Frequency (\%) \\
\hline Gender & 150 & 50 \\
\hline Female & 150 & 50 \\
\hline Male & & \\
\hline Age (years) & 902 & 34 \\
\hline $18-30$ & 99 & 33 \\
\hline $40-45$ & 99 & 33 \\
\hline
\end{tabular}




\begin{tabular}{|c|c|c|}
\hline Education & & \\
\hline Elementary school & 63 & 21 \\
\hline High school & 66 & 22 \\
\hline Undergraduate & 153 & 51 \\
\hline Graduate & 18 & 6 \\
\hline \multicolumn{3}{|l|}{ Marital status } \\
\hline Single & 99 & 33 \\
\hline Married & 171 & 57 \\
\hline Divorced or widowed & 30 & 10 \\
\hline \multicolumn{3}{|l|}{ Occupation } \\
\hline Full-time labourer and employee & 111 & 37 \\
\hline Student & 108 & 36 \\
\hline Unemployed & 36 & 12 \\
\hline Retiree & 21 & 7 \\
\hline Housewife & 21 & 7 \\
\hline Part-time labourer & 3 & 1 \\
\hline \multicolumn{3}{|l|}{ Monthly household income (Turkish Lira) } \\
\hline$<500$ & 3 & 1 \\
\hline $500-1000$ & 48 & 16 \\
\hline $1000-1500$ & 21 & 7 \\
\hline $1500-2000$ & 48 & 16 \\
\hline $2000-2500$ & 51 & 17 \\
\hline $2500-3000$ & 45 & 15 \\
\hline$>3000$ & 84 & 28 \\
\hline
\end{tabular}

Consumers' knowledge about health effects of edible oils and fats

A total of $26 \%$ of the participants stated that olive oil was the most useful oil in terms of human nutrition (Figure 1). Similar survey results were obtained in different cities of Turkey. A survey study carried out in Ankara, the capital of Turkey, showed that $80 \%$ of the 400 participants reported olive oil as the top contributor to human health [26], Whereas $89.70 \%$ of the respondents in Tekirdağ stated that olive oil was the most healthful oil [37]. Among all, sunflower oil was ranked second and butter third by Turkish consumers. The most surprising output of this question is more than one-tenth of the participants believed that margarine had a positive effect on human health $(12 \%, n=36)$. Probably, due to very limited use of soybean oil in Turkey, any Turkish consumers did not rank this oil in this question.

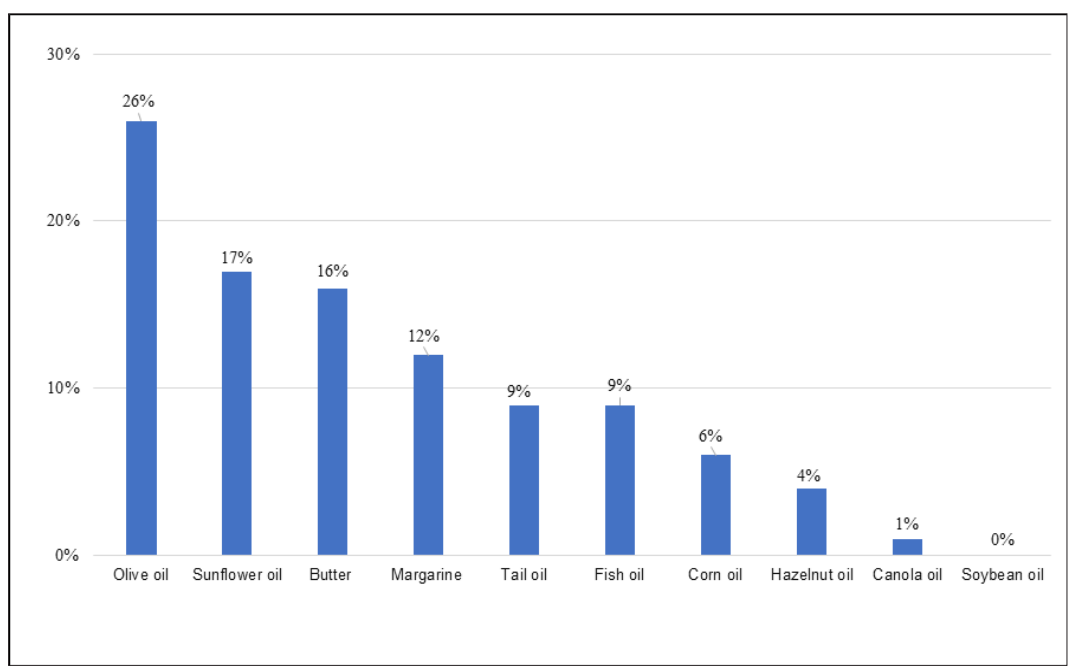

Figure 1: Ranking of edible oils and fats regarding health benefits. 
Figure 2 shows participants evaluation of each edible oil and fat in terms of health effects. Butter, olive oil, fish oil, sunflower oil, corn oil, and hazelnut oil were classified as beneficial oils $(92.33 \%, 89 \%$, $79.70 \%, 73.67 \%, 61 \%$, and $58 \%$, respectively), whereas margarine was reported to be unbeneficial by most of the participants (93.33\%, n=280). Fish oil capsules have been marketed as dietary supplement in Turkey for many years. So, Turkish individuals are aware of its health benefits. The opinion of participants about health effect of margarine seemed confused. In the first question, $12 \%$ of the participants reported margarine as useful in terms of nutrition. However, in the second question, majority of them stated that margarine was unbeneficial regarding to health effects. It is very hard to discuss these conflicting results. Finally, the awareness of the participants about health effects of canola oil was scarce. A total of $36 \%$ and $27 \%$ of the participants stated that they had no idea, or they had never heard before. Contrary to our results, a survey study carried out in Italy showed that butter was believed to be unbeneficial by participants [41]. The different attitudes of various societies may be attributed to different dietary habits. In Mediterranean culture, olive oil dominates the diet. On the other hand, butter is as popular as olive oil in Turkish cuisine. Hence, the perceptions of the consumers may be influenced by social habits.

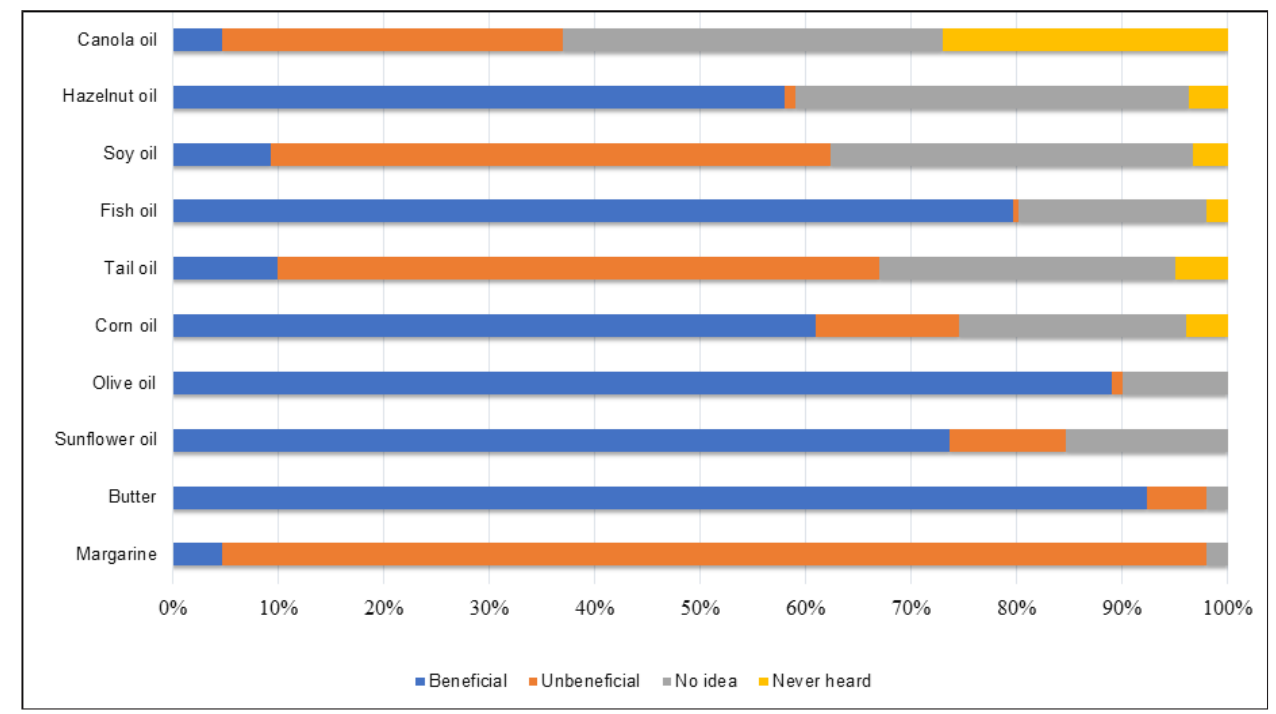

Figure 2: Participants attitudes towards the health effects of each oil and fat surveyed in the questionnaire.

The percentages of participants who reported their ideas about health effects of edible oil and fat consumption are summarized in Table 2. According to findings of this survey, only a little more than one-tenth of participants stated that the amount of oil in the diet should be reduced $(12 \%, \mathrm{n}=36)$, while almost half of them believed amount of fat in the diet should be decreased (43\%, $n=129)$. In a survey dealing with fat consumption habits and attitudes of Dutch and American individuals, $26.40 \%$ of American participants were willing to adopt a low-fat diet, while positive statement for same question was reported by only $6.90 \%$ of Dutch respondents [30]. Moreover, $75 \%$ of the participants reported that consumption of oils in moderation would not pose a health risk. On the other side, only one-third of the participants had the same opinion for fats $34 \%$, $n=102$ ). This apparent difference indicates that fats are considered more harmful than oils in terms of health by the participants.

Table 2: Participants' thoughts about health effects of edible oils and fats consumption.

\begin{tabular}{|c|c|c|c|c|}
\hline \multirow{2}{*}{ Do you think Consumption of Edible Oil/Fat may cause a Health Concern... } & \multicolumn{2}{|r|}{ Oil } & \multicolumn{2}{|r|}{ Fat } \\
\hline & $\mathbf{n}$ & Frequency $(\%)$ & $\mathbf{n}$ & Frequency $(\%)$ \\
\hline Yes, it is harmful due to its cholesterol content & 12 & 4 & 48 & 16 \\
\hline Yes, the amount of it in the diet should be reduced & 36 & 12 & 129 & 43 \\
\hline It is not harmful if it is not consumed too much & 225 & 75 & 102 & 34 \\
\hline No idea & 27 & 9 & 21 & 7 \\
\hline
\end{tabular}


Fats including butter and margarine were regarded as the riskiest item in terms of health by 279 participants out of total 300 (Figure 3). As stated in the previous research question, the reliability of fruit oils, principally olive oil, in terms of health was confirmed by the participants. The surprising output of this survey is majority of Turkish consumers believed fats pose a health risk as seen in Figure 3 (93\%, n=279). However, as shown in Table 2, less than half of the participants were willing to reduce the amount of fat in their diet $(43 \%, n=129)$. This suggests that health risk is not considered as an important determinant for fat consumption in the daily diet by Turkish consumers. Individuals commonly prefer to use fats to improve the palatability of various kinds of foods in Turkey. This means that palate of consumers clearly outweighs the health risk of fats.

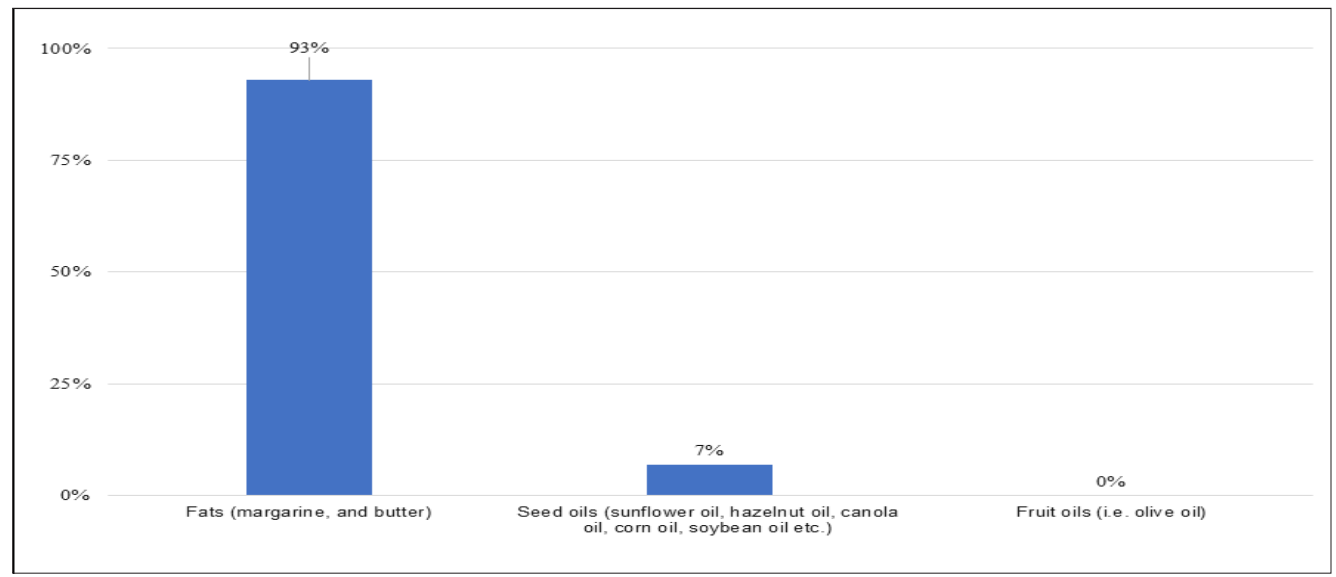

Figure 3: The ranking of oil groups in terms of their health risks by participants.

As shown in Figure 4, 210 participants out of 300 reported margarine to be the richest source of cholesterol. Butter was ranked second highest cholesterol content by the participants of this survey. Interestingly, despite its limited use and awareness of consumers in Turkey, soybean oil was reported as a cholesterol source by $7 \%$ of the participants. Concerning intake of oils and fats, $52 \%$ of the participants indicated that they tried to decrease their intake. On the other hand, almost one-third of the participants felt they would not be able to decrease their daily intake (34\%, $n=102) .30$ participants out of a total of 300 reported that they tried to decrease butter intake they consumed in the breakfast. The remaining sample of 12 participants stated that they consumed only olive oil $(3 \%, n=9)$ or vegetable oil $(1 \%, n=3)$.

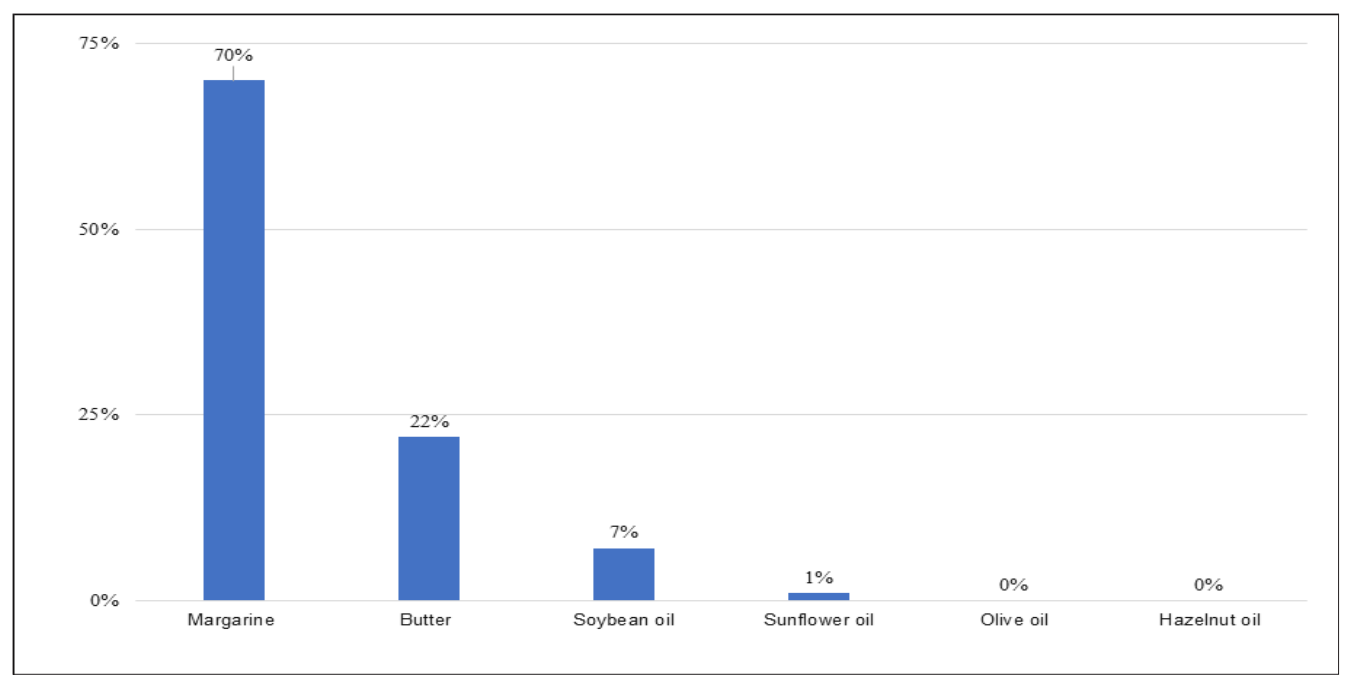

Figure 4: The ranking of edible oils and fats in terms of cholesterol content by the participants.

Regarding the relationship between oil/fat consumption and cardiovascular diseases, more than half of the participants believed that cardiovascular diseases were associated with oil/ fat consumption $(76 \%, n=228)$, while only $5 \%$ of them disagreed (Figure 5). Almost one-tenth of the respondents reported that these food items were as related as other foods in terms of cardiovascular diseases formation $(11 \%, \mathrm{n}=33)$. The remaining subjects $(8 \%$, $\mathrm{n}=24$ ) did not have any idea about this issue. This proportion is in accordance with the proportions of participants declared no idea about the possible health effects of oil and fat consumption, $9 \%$ and $7 \%$, respectively (Table 2 ). 


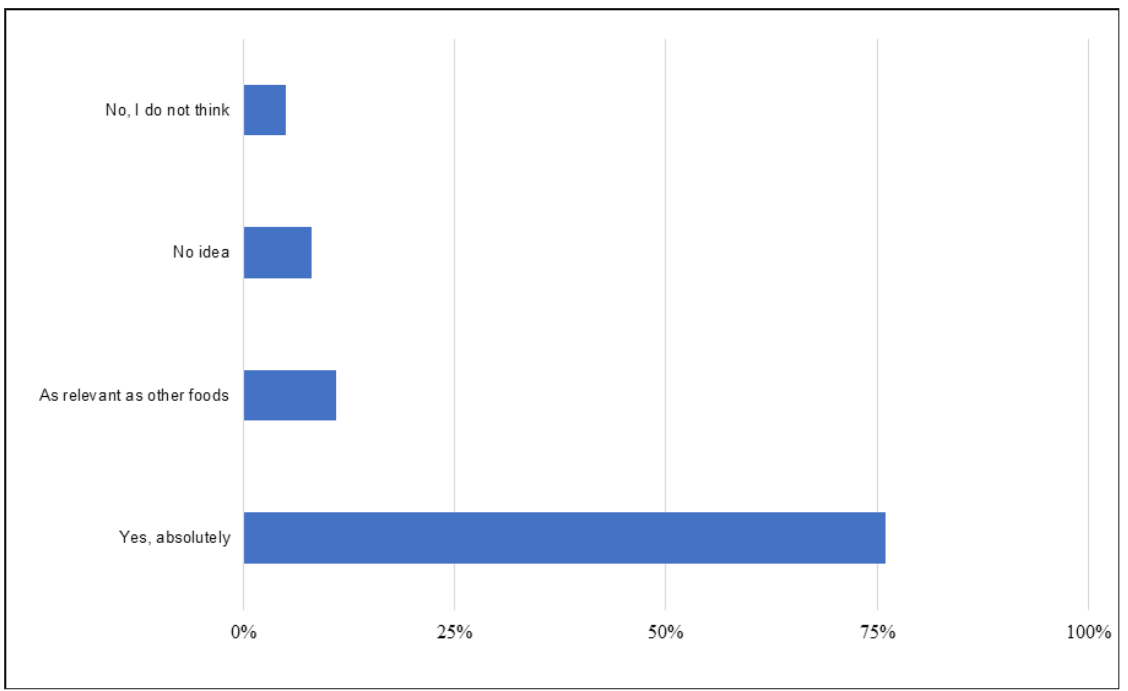

Figure 5: Participants thoughts about relationship between oil/fat consumption and cardiovascular diseases formation.

According to the data illustrated in Figure 6, the consumers had completely opposite opinions about cholesterol-raising effect of butter. Of the participants, 39\% indicated that butter consumption would increase cholesterol levels, while $38 \%$ believed butter had no cholesterol-raising impact. It is noteworthy that substantial part of the respondents, almost one-fifth of them $(23 \%, n=69)$, was unaware about the effect of butter on cholesterol levels. As shown in Table 1, more than half of the participants of this survey held at least a high school degree $(79 \%, \mathrm{n}=237)$. Hence, this surprising high level of unawareness might be attributed to less concerns of Turkish consumers toward health issues related to diet.

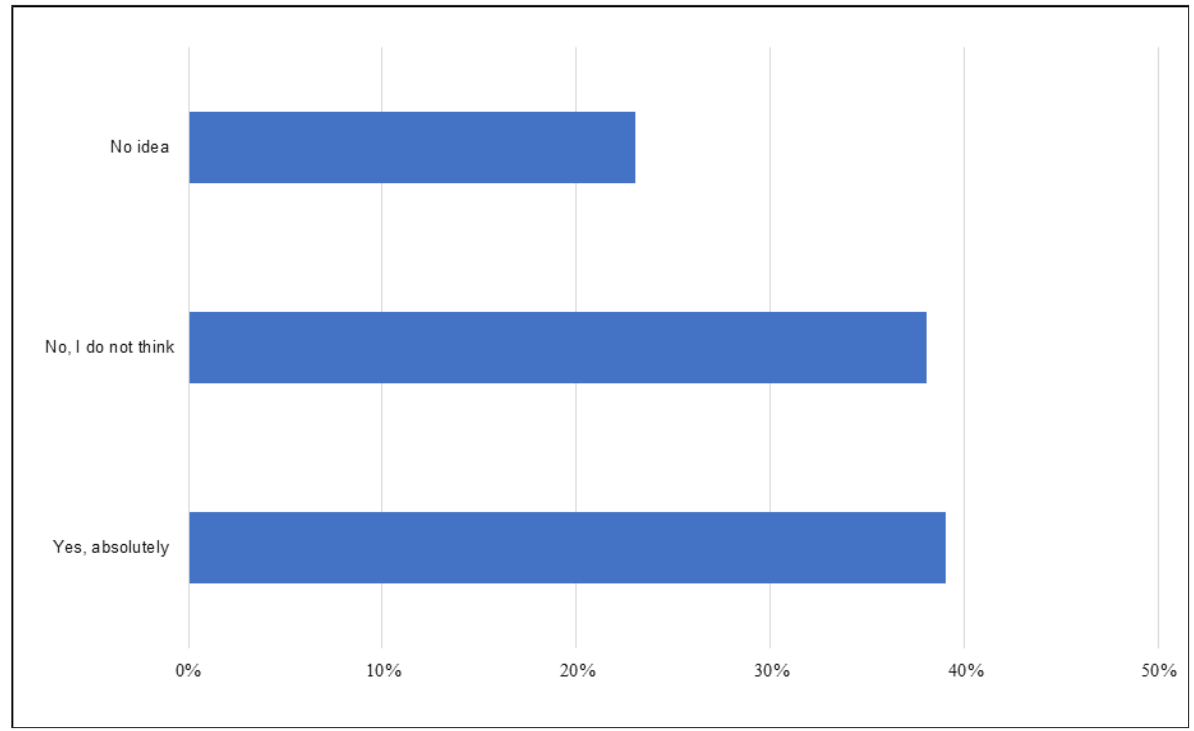

Figure 6: Participants beliefs about cholesterol-raising effect of butter.

Figure 7 illustrates the comparison of various oil/fat couples in terms of nutritiousness by 300 participants. In general, olive oil was considered as the most nutritious item among all. Then, butter was commonly preferred in different dual comparison groups. However, $65 \%$ of the participants preferred olive oil over butter in terms of nutritiousness. Of the participants, $68.33 \%$ and $71 \%$ believed corn oil and sunflower oil were more nutritious than margarine. This attitude is desirable for consumers to be motivated to decrease their daily fat intake. Sunflower and corn oils are widely used for culinary purposes in Turkey. Hence, the proportions of respondents who preferred corn oil (56.33\%, $\mathrm{n}=169)$ and sunflower oil $(43.67 \%$, $\mathrm{n}=131$ ) in dual comparison group (sunflower oil/corn oil) were close to each other. 


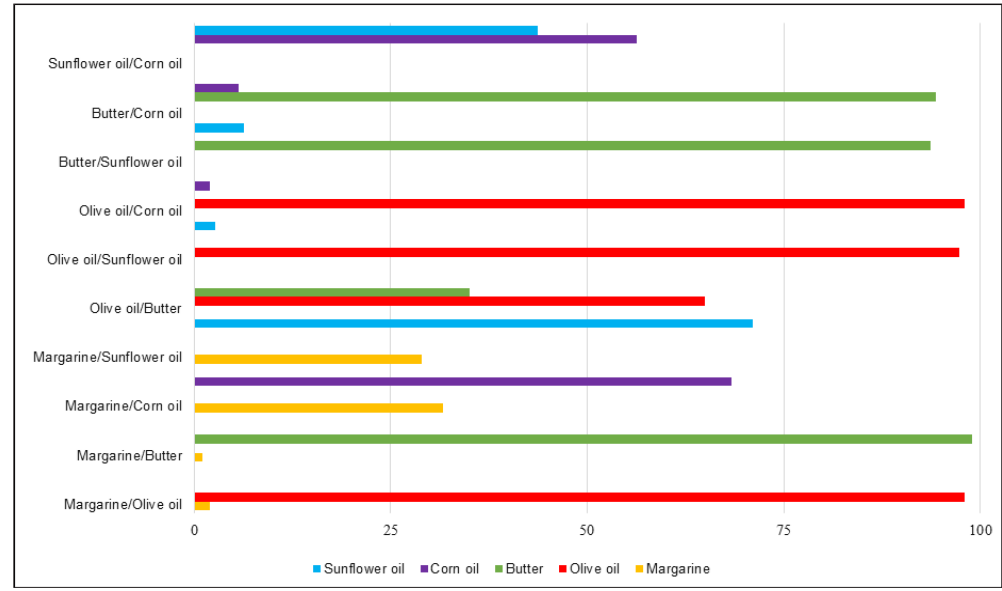

Figure 7: Comparison of oil/fat couples regarding nutritiousness by participants (\%).

As shown in Figure 8, olive oil was perceived as the most healthful oil by the participants. In all dual comparison groups, olive oil prevailed over its all counterparts. Except olive oil-butter comparison, butter was regarded as more healthful item than its correspondent in all comparison groups. In contrast to results of previous question (Figure 7), 62\% of the participants reported that sunflower oil was more healthful than corn oil (Figure 8). Further survey studies may focus on the perceptions of Turkish consumers about nutritiousness and healthiness of food items. This survey study has some limitations. Firstly, sample size (300 participants) is not enough to generalize the results of this study to all Aegean region of Turkey. Second, number of participants from each sociodemographic group should be balanced to reduce variability.

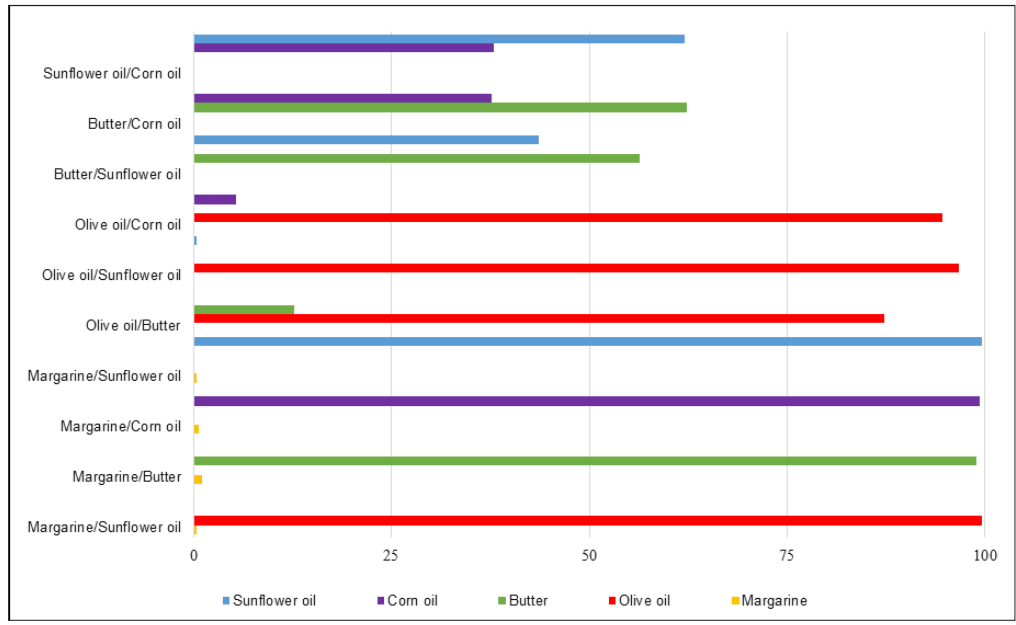

Figure 8: Comparison of oil/fat couples regarding health benefits by participants (\%).

\section{Conclusion}

In summary, results indicate that tendency of the participants mainly focused on the popularity and availability of items surveyed in this study. Olive oil was considered the most popular healthy oil, whereas margarine was regarded harmful. It is speculated that the awareness of the participants derived from interviews of some medical doctors shown in TV shows or found in newspapers/ magazines. Moreover, social media is also responsible for knowledge sharing. Soybean oil, an uncommon oil commodity for Turkish consumers, was not generally evaluated or classified by the participants. Efforts are needed to promote health benefits and availability of other seed oils in Turkey.

\section{References}

1. Scrimgeour C (2005) Chemistry of fatty acids. In: Shahidi (Ed.), Bailey's Industrial Oil and Fat Products. (6 ${ }^{\text {th }}$ edn), pp. 1-39.

2. Tarhan Ö (2008) The analysis of frequently consumed various cooking oil in Turkey and fatty acid compositions of fatty seeds with gas chromatography. Karadeniz Technical University Institute of Science, Turkey.

3. Başoğlu F (2017) Yemeklik Yağ Teknolojisi. Dora Yayınları, Bursa, Turkey.

4. Gündüz O, Esengün K (2010) A study on vegetable oil consumption of families: The case of Samsun province. KMÜ Social and Economics Research Journal 12(19): 67-72.

5. Dunford NT (2004) Oil-and oilseed-based bioactive compounds and their health effects. In Nutritionally enhanced edible oil and oilseed processing, pp. 1-30. 
6. Youssef MK, Barbut S (2011) Fat reduction in comminuted meat products-effects of beef fat, regular and pre-emulsified canola oil. Meat Science 87(4): 356-360.

7. Öğütcü M (2014) Preparation of edible oleogels and evaluation of their food product usabilities. Çanakkale Onsekiz Mart University Institute of Science.

8. Harwood JL, Evans M, Ramji D, Murphy DJ, Dodds PF (2007) Medical and agricultural aspects of lipids. In: Gunstone, Harwood, Dijkstra (Eds.), The Lipid Handbook. ( ${ }^{\text {rd }}$ edn), pp. 703-756.

9. Hennig B (2005) Dietary lipids and health. In: Shahidi (Ed.), Bailey's industrial oil and fat products, pp. 577-600.

10. Arığlu H (2016) Türkiyede Yağlı Tohum ve Ham Yağ Üretimi, Sorunlar ve Çözüm Önerileri. Tarla Bitkileri Merkez Araştırma Enstitüsü Dergisi 25: $357-368$

11. Onat B, Arıoğlu H, Güllüoğlu L, Kurt C, Bakal H (2017) Dünya ve türkiyede yağli tohum ve ham yağ üretimine bir bakıș. KSÜ Doğa Bilimleri Dergisi 20: 149-153.

12. Krauss RM (2001) Executive summary of the third report of the national cholesterol education program (NCEP) expert panel on detection, evaluation, and treatment of high blood cholesterol in adults (Adult Treatment Panel III). JAMA 285(19): 2486-2497.

13. AHA (2019) American heart association recommendation.

14. FDA (2019) Food and drug administration.

15. Saboo B, Singh RB, Bhardwaj K, Maheshwari A, Verma N, Vargova V, Daniel P (2019) Fats and oils for health promotion and disease prevention. In: Singh RB, Watson RR (Eds.), The Role of Functional Food Security in Global Health, pp. 273-285.

16. Griffith GR, Meilke KD (1979) Relationships among North American fats and oils prices. American Journal of Agricultural Economics 61(2): 335341.

17. Onurlubaş HE, Kızılaslan H (2007) Türkiyede bitkisel yağ sanayindeki gelişmeler ve geleceğe yönelik beklentiler.

18. Choi YS, Park KS, Kim HW, Hwang KE, Song DH, Choi S, Lee SY, Paik HD, Kim CJ (2013) Quality characteristics of reduced-fat frankfurters with pork fat replaced by sunflower seed oils and dietary fiber extracted from makgeolli lees. Meat Science 93(3): 652-658.

19. Noreen S, Ashraf M (2010) Modulation of salt ( $\mathrm{NaCl}$ )-induced effects on oil composition and fatty acid profile of sunflower (Helianthus annuus L.) by exogenous application of salicylic acid. Journal of the Science of Food and Agriculture 90(15): 2608-2616.

20. Upadhyay R, Mishra HN (2015) Predictive modeling for shelf life estimation of sunflower oilblended with oleoresin rosemary (Rosmarinus officinalis L.) and ascorbyl palmitate at low and high temperatures. LWTFood Science and Technology 60(1): 42-49.

21. Wong YH, Goh KM, Nyam KL, Nehdi IA, Sbihi HM, et al. (2019) Effects of natural and synthetic antioxidants on changes in 3-MCPD esters and glycidyl ester in palm olein during deep-fat frying. Food Control 96: 488493.

22. Gavahian M, Khaneghah AM, Lorenzo JM, Munekat PES, Mantrana IG, et al. (2019) Health benefits of olive oil and its components: Impacts on gut microbiota antioxidant activities, and prevention of noncommunicable diseases. Trends in Food Science and Technology 88: 220-227.

23. Foscolou A, Critselis E, Panagiotakos D (2018) Olive oil consumption and human health: A narrative review. Maturitas 118: 60-66.
24. Ağır M, Boran C, Özden F, Artukoğlu MM (2018) Zeytinyağında tüketici tercihleri üzerine bir araștirma: İzmir ili dikili ilçesi örneği. Ege Üniversitesi Ziraat Fakültesi Dergisi 55(4): 81-90.

25. Akbay C (2007) Urban households cooking oil and fat consumption patterns in Turkey: Quality Vs. Quantity 41(6): 851-867.

26. Cömert M, Adıyaman S, Özkaya FD (2012) Identifying local people's knowledge level about olive oil: Example from Golbasi, Ankara. Zeytin Bilimi 3(1): 1-9.

27. Delgado C, Rico AG, Guinard JX (2013) Evaluating bottles and labels versus tasting the oils blind: Effects of packaging and labeling on consumer preferences, purchase intentions and expectations for extra virgin olive oil. Food Research International 54(2): 2112-2121.

28. Diekman C, Malcolm K (2009) Consumer perception and insights on fats and fatty acids: Knowledge on the quality of diet fat. Annals of Nutrition and Metabolism 54(Suppl 1): 25-32.

29. Eckel RH, Etherton PK, Lichtenstein AH, Rosett JW, Groom A, et al. (2009) Americans' awareness, knowledge, and behaviors regarding fats: 20062007. Journal of the American Dietetic Association 109(2): 288-296.

30. Glanz K, Brug J, Assema PV (1997) Are awareness of dietary fat intake and actual fat consumption associated? -A Dutch American comparison. European Journal of Clinical Nutrition 51(8): 542-547.

31. Göktaş B, Gül V (2018) Türkiye'de tüketicilerin yağ alişkanliklari ve satin aldiklari markalara yönelik düșünceler. In: Temizer, Baytal (Eds.), Sosyal Bilimlerde Yeni Yönelimler-V. ( $1^{\text {st }}$ edn), Turkey.

32. Harel Z, Riggs S, Vaz R, White L, Menzies G (2001) Omega-3 polyunsaturated fatty acids in adolescents: knowledge and consumption. Journal of Adolescent Health 28(1): 10-15.

33. Küçükkömürler S, Uluksar FO (2018) Türk mutfak kültüründe zeytinyaği kullanimı; muğla örneği (Use of olive oil in Turkish cuisine culture, case of muğla). Journal of Tourism and Gastronomy Studies 6(2): 194-212.

34. Lin CTJ, Yen ST (2010) Knowledge of dietary fats among us consumers. Journal of the American Dietetic Association 110(4): 613-618.

35. Sayılı M, Gözener B, Kalpakoğlu G (2013) Ordu ili merkez ilçede ailelerin findik yaği tüketim durumlari. Gaziosmanpaşa Üniversitesi Ziraat Fakültesi Dergisi 30(1): 84-90.

36. Tunalığlu R, Cankurt M, Çobanoğlu, F, Armağan G (2012) Zeytinyağı tüketici davranişları. In 10.Ulusal Tarım Ekonomisi Kongresi, pp. 853862 .

37. Unakıtan G, Bașaran B, Yılmaz F (2012) Analysis of preferences of olive oils consumption in tekirdağ province. In 10. Ulusal Tarım Ekonomisi Kongresi, Konya, Turkey, pp. 956-963.

38. Yıldız Z, Yılmaz V, Kaşkır F, Baș M (2012) Çok değișkenli istatistiklerle tüketicilerin sivi yă̆ ambalaj tercihlerine göre bölümlendirilmesi. Dumlupınar Üniversitesi Sosyal Bilimler Dergisi 32(1): 25-272.

39. https://tuik.gov.tr/Start.do

40. Paul N, Carlson WL, Thorne BM (2013) Statistics for business and economics. In: James, Benson (Eds.), Pearson Education Limited, Essex, England, UK.

41. Saba A, Natale R (1998) Attitudes, intention and habit: Their role in predicting actual consumption of fats and oils. Journal of Human Nutrition and Dietetics 11(1): 21-32. 